\title{
Proliferation and apoptosis of human placental cells exposed to aromatic hydrocarbons
}

\author{
Waldemar Wierzba ${ }^{1}$, Piotr Tyszko ${ }^{2}$, Krzysztof Kanecki ${ }^{3}$, Jarosław Pinkas ${ }^{4}$ \\ ${ }^{1}$ University of Humanities and Economics in Lodz, Satellite Campus in Warsaw, Poland \\ ${ }^{2}$ Institute of Rural Health, Lublin, Poland \\ ${ }^{3}$ Medical University of Warsaw, Poland \\ ${ }^{4}$ Centre of Postgraduate Medical Education, Warsaw, Poland
}

\begin{abstract}
Objectives: The objective of this study is to assess the effect of elevated urinary levels of aromatic hydrocarbons (AH) on the proliferation and apoptosis of human placental trophoblast cells obtained in the course of normal pregnancy in an $\mathrm{AH}$-polluted region.

Material and methods: Tissue material was obtained for study purposes from 50 afterbirths from Płock as the study group and 50 afterbirths from Kutno as the control group. The extent and intensity of reactions were analyzed. The levels of phenol and 1-hydroxypyrene in the excreted urine of pregnant (in labor) patients were determined by gas chromatography and colorimetry. The proliferative activity of trophoblast cells was assessed using MPM-2 antibodies against phosphoprotein synthesized upon mitotic induction and Ki-67 antigen while the intensity of apoptosis in trophoblast cells was assessed using $\mathrm{p} 53$ and bcl-2 oncoproteins involved in apoptosis-regulating mechanisms. The immunohistochemical reactions were assessed for their extent and intensity.

Results: The levels of phenol and 1-hydroxypyrene excreted in the urine were statistically significantly higher in patients from Płock region. The proliferative activity of trophoblast cells was statistically significantly higher in the study group $(p<0.05)$. The activity of oncoprotein bcl-2 was significantly higher in the study group while the activity of p53 was significantly higher in the control group.

Pregnancy in an aromatic hydrocarbon-polluted environment has a significantly negative impact on placental tissue. Adaptation mechanisms are induced as manifested by increased proliferative activity within the trophoblast and extensive inhibition of apoptosis in the study group.
\end{abstract}

Key words: human placenta, aromatic hydrocarbons, phenol, 1-hydroxypiren

\section{INTRODUCTION}

Human placenta is an organ that plays a very important role in human life. In the fetal stage of development, placenta plays the role of fetal lungs, alimentary tract, kidneys, and the entire endocrine gland system including the liver. Placenta is used to transfer metabolic products and acts as the site of production or metabolic transformation of hormones and enzymes essential for the developing pregnancy [1-3]. As an organ, the placenta is functional within a precisely defined time frame, with the processes of apoptosis, i.e. programmed placental cell death, playing an important and evident role [4].

The placenta is an organ characterized by high intrinsic metabolic activity. Individual components of this activity, and particularly the functional efficiency thereof are factors that determine the welfare of the fetus. In light of the studies conducted to date, trophoblast epithelium appears to be the most active part of the afterbirth. The proliferative activity of the placental tissue is regulated by mechanisms responsible for mother-fetus exchange and the process 
of oxygen delivery through the basal membrane of the trophoblast within the terminal villi $[5,6]$.

Aromatic hydrocarbons, particularly phenol, are characterized by high toxicity against a number of cellular structures such as parenchymal organs (liver, lungs, placenta) and the hematopoietic system, including the human placenta [7-9]. Some authors observed trophoblastic epithelial damage, extensive remodeling and recovery, as well as delayed and reduced activity of dehydrogenases within human placentae collected from residents of regions located in the vicinity of petrochemical plants presenting with high urinary excretion of phenol [10-12]. The placental barrier that separates the maternal circulation from the fetal circulation provides a somewhat limited protection against chemical substances reaching the fetus.

Aromatic hydrocarbons, including benzene derivatives whose atmospheric levels are significantly higher in regions located in the vicinity of refining/petrochemical plants lead to hazardous chronic intoxications which, while progressing in an asymptomatic manner, lead to extensive damage to the organs and tissues after longer exposure.

Significantly higher urinary levels of phenols and 1-hydroxypyrene, i.e. metabolites of benzene derivatives being excreted with urine, are the markers of such an intoxication [13-16].

The impact of aromatic hydrocarbon pollution on parenchymal organs is assessed in the examinations of afterbirths obtained from normal pregnancies that were developing in elevated phenol level conditions as compared to the afterbirths from regions not polluted with substances of this type.

The objective of this study is to assess the effect of the elevated levels of aromatic hydrocarbons excreted in the urine on the proliferative activity and apoptosis of trophoblast cells within the terminal villi of the human placenta.

\section{MATERIAL AND METHODS}

The study material was collected from patients whose pregnancies developed in Płock region in an environment exposed to elevated atmospheric levels of aromatic hydrocarbons (HA). The control group consisted of patients whose pregnancies developed in Kutno, i.e. outside of the hydrocarbon-polluted region. The criterion for the afterbirth to be qualified for the study consisted of an uncomplicated, physiological course of pregnancy completed by an in-term delivery (weeks 39-41). All the observed pregnancies were completed by natural deliveries of healthy neonates (Apgar score 10). Before the pregnancy, patients were free of chronic diseases, smoking, and alcohol or drug abuse. There were no statistically significant differences between the study group and the control group in terms of age, parity, and body weight. There were no significant differences in the birth weights of children born of the analyzed pregnan- cies. In each patient, urinary phenol levels were assessed three times during pregnancy and once upon the delivery as an indicator of the total exposure to hydrocarbons. This is due to the fact that the hydrocarbons metabolites excreted in urine present with the features of simple phenols. The phenol levels were assessed using three methods: colorimetric reactions with 4-aminoantipyrine, gas chromatography (GC) and high performance liquid chromatography (HPLC). Simultaneously, urinary levels of 1-hydroxypyrene were determined by means of gas chromatography as a biological marker of exposure to polycyclic aromatic hydrocarbons.

Tissue material was obtained for study purposes from 50 afterbirths from Płock as the study group and 50 afterbirths from Kutno as the control group. In each case, two umbilical cord specimens, one extraplacental membrane specimens and two or three specimens of the placenta itself were collected. All 550 specimens obtained were processed technologically into paraffin blocks. Sections were obtained from the paraffin blocks for routine histopathological assessment; based on this assessment, the most representative placental specimens were selected for further immunohistochemical processing. Histopathological assessment was performed using basic hematoxylin and eosin staining. The results of preliminary assessments revealed no significant histopathological differences in both groups of placental specimens, i.e. specimens from the Płock region and specimens from the Kutno region.

Next, immunohistochemical reactions were carried out on selected specimens of 50 afterbirths from the environmentally polluted region of Płock and of 50 afterbirths from the Kutno region being processed as the control group. The obtained results, i.e. the intensity and extent of immunohistochemical reactions were used as the basis for comparative analysis of the expression of individual reaction products. Immunohistochemical reactions were carried out with sera for tracing the protein products of oncogenes involved in the mechanisms regulating the apoptosis ( $\mathrm{bcl}-2$, p53). Apoptosis is a genetically-determined mechanism that is morphologically identical to the physiological process of programmed cell death. In physiological conditions, programmed cell death occurs in the course of organogenesis, regulates the number of cells during growth and remodeling (e.g. upon formation of the gastrointestinal tract lumen or upon the development of morphologically mature skin). Cyclical apoptosis is observed e.g. in the endometrium.

Immunohistochemical reactions were carried out by the peroxidase method using LSAB kits (HRP Rabbit/Mouse - Universal LSAB 2 Kits from DAKO, Denmark). The kits are based on the sequential use of biotinylated antibody linkers traced with streptavidin with horseradish peroxidase. The method is very sensitive as it facilitates the detection of low concentrations of original antibodies. 
Immunohistochemical reactions were carried out with the following antibodies:

- Antibodies for the detection of proliferative activity, particularly within trophoblast cells:

1. Mo a MPM-2 (Anti-Mitotic Protein); phosphoprotein synthesized upon mitotic induction tags the MPM-2 antigen in both mitotic and interphase cells.

2. Rb a Hu Ki 67 tags the proliferating cells thus disclosing the expression of antigen $\mathrm{Ki}-67$ within the cells in the cell cycle phases of G1, S, M, G2 except for G 0 .

- Antibodies for the detection of apoptosis within the placental tissue, particularly with regard to the trophoblast cells that constitute the most active part of the placental tissue:

1. Mo a Hu p53; p53, an oncoprotein known as a regulator of cell proliferation, is involved in the mechanisms that regulate apoptosis. It is assumed that p53 acts by inhibiting oncoprotein bcl-2 known to be an apoptosis inhibitor;

2. Mo a Hu bcl-2 for the detection of the expression of oncoprotein bcl-2 in trophoblast cells; bcl-2 is known to be an apoptosis inhibitor.

The reactions were assessed by dual means. In the first method, the reactions were assessed using an arbitrary scale of 0 to 3 points where $0=$ no reaction, and $3=$ strong, homogeneous reaction.

In addition, the immunohistochemical reactions were assessed for their extent and intensity by means of computer-assisted morphometric analysis using the Cell Soft Imaging System (Olympus). This was facilitated by coupling an optical microscope with a digital camera (Olympus BX41, Olympus (3040) to a computer system. This assessment allowed for objectivization of the immunohistochemical results. The differences were considered to be statistically significant at the significance level of $95 \%(p<0.05)$.

The results were subjected to statistical analysis using PQStat Software v.1.6.1. Student's t-test and the chi-square test of independence were used.

\section{RESULTS AND DISCUSSION}

The levels of phenol and 1-hydroxypyrene excreted in the urine were statistically significantly higher in patients from Płock region (Table 1).

The average size of placenta in Płock region was higher than the average size of placenta in Kutno region; however, the difference was not statistically significant $(p=0.064)$.

The proliferative activity of trophoblast cells was assessed by means of the expression of mitotic phosphoprotein (Mo a MPM-2 Anti Mitotic Protein) which tags the MPM-2 antigen both in the mitotic cells and in the interphase cells and by means of the expression of Ki 67 (Rb a Hu Ki 67) in specific cell cycle phases (G1, S, M, G2 excluding G0) of proliferating cells. Calculations revealed a significantly higher activity and the extent of mitotic phosphoprotein $(p<0.01)$ (Tables 2, 3).

For all reactions described below, calculation was performed as in Tables 2 and 3. These tables are not located in the text, due to the transparency of the publication. Describes only the results.

Calculations revealed also a significantly higher activity and extent of the Ki 67 antigen ( $p<0.01)$ in trophoblast cells collected from the study group (Płock) as compared to the control group (Kutno).

The occurrence of apoptosis in trophoblast cells which constitute the most active part of the placental tissue was as-

Table 1. The urine levels of excreted phenol and 1-hydroxypyrene in pregnant women

\begin{tabular}{|c|c|c|c|c|}
\hline Study groups & $\begin{array}{l}\text { Phenol met. Hplc [mg/L] } \\
\text { (X } \pm \text { SD) }\end{array}$ & $\begin{array}{l}\text { Phenol met. Gc }[\mathrm{mg} / \mathrm{L}] \\
(\mathrm{X} \pm \mathrm{SD})\end{array}$ & 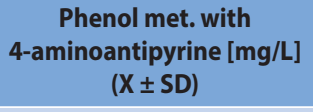 & $\begin{array}{c}\text { 1-hydroxypyrene [mg/L] } \\
(X \pm S D)\end{array}$ \\
\hline $\begin{array}{l}\text { KUTNO } \\
n=50\end{array}$ & $2.025 \pm 0.767$ & $2.044 \pm 0.754$ & $5.059 \pm 0.788$ & $0.225 \pm 0.169$ \\
\hline $\begin{array}{l}P Ł O C K \\
n=50\end{array}$ & $4.419 \pm 2.484$ & $4.455 \pm 2.624$ & $8.735 \pm 2.835$ & $0.519 \pm 0.366$ \\
\hline $\begin{array}{l}\text { t-Student test for } \\
\text { independent samples }\end{array}$ & $\begin{array}{c}t=6.5115 ; k=98 \\
p<0.001\end{array}$ & $\begin{array}{c}t=6.2443 ; k=98 \\
p<0.001\end{array}$ & $\begin{array}{c}t=8.8337 ; k=98 \\
p<0.001\end{array}$ & $\begin{array}{c}t=5.156831 ; k=98 \\
p<0.001\end{array}$ \\
\hline
\end{tabular}

Table 2. Immunoexpression of mitotic phosphoprotein in trophoblast cells

\begin{tabular}{|l|c|c|c|}
\hline \multirow{2}{*}{ Groups } & \multicolumn{3}{|c}{ The intensity of the reaction } \\
\cline { 2 - 4 } & No reaction & Trace reaction & Poor reaction \\
\hline Study group $(n=50)$ & $3(6 \%)$ & $15(30 \%)$ & $25(50 \%)$ \\
\hline Control group $(n=50)$ & $7(14 \%)$ & $24(48 \%)$ & $19(38 \%)$ \\
\hline Chi-square test of independence & Chi-square statistics $=11.495 ;$ degrees of freedom $=3 ; p$-value $=0.009$ & $0(14 \%)$ \\
\hline
\end{tabular}


Table 3. The extent of the color reaction of mitotic phosphoprotein in trophoblast cells

\begin{tabular}{|l|c|c|c|} 
& Number & \multicolumn{2}{|c}{ Average area \pm standard deviation } \\
\cline { 3 - 4 } Groups & $(\mathbf{n})$ & {$\left[\mathrm{m}^{2}\right]$} & $3.85 \pm 3.38$ \\
\hline Study group (Płock) & 50 & $5539.33 \pm 4867.44$ & $1.62 \pm 1.28$ \\
\hline Control group (Kutno) & 50 & $2332.66 \pm 1854.58$ & $\mathrm{t}=4.35 ; \mathrm{k}=98$ \\
\hline & & $\mathrm{t}=4.35 ; \mathrm{k}=98$ & $\mathrm{p}<0.001$
\end{tabular}

sessed by means of determination of oncoprotein p53 levels (Mo a Hu p53). Oncoprotein p53 is a factor that regulates the proliferative activity of cells and takes part in mechanisms that regulate apoptosis by inhibiting oncoprotein bcl-2. In addition, the activity of oncoprotein bcl-2, which is an inhibitor of apoptosis, was assessed (Mo a Hu bcl-2). The results of the analyses confirmed the significantly higher expression of bcl-2 in the study group ( $p<0.01$ ) and the significantly higher expression of p53 in the control group $(p<0.01)$.

The PKN Orlen petrochemical plant emits over 100,000 tons of gases, including compounds of sulfur, nitrogen, benzene and its derivatives such as benzopyrene and phenol. Despite the fact that no air pollution thresholds being in force in Poland (and very liberal towards the industrial polluters) were exceeded during the study period and in the study region, the levels of phenol excreted in the urine of pregnant women from the Płock region as measured by three separate methods and the levels of 1-hydroxypyrene were significantly higher than those in pregnant women from the Kutno region. Phenol is the main metabolite of the decomposition of aromatic hydrocarbons in the human body while 1-hydroxypyrene is a biological marker of exposure to polycyclic aromatic hydrocarbons [13, 14, 16].

This suggests that the environment in the vicinity of the petrochemical plant is polluted with the aforementioned industrial pollutants that contain significant quantities of hydrocarbons while all the pregnant women included in the study were significantly exposed to these substances. The results obtained by other authors confirm the high levels of phenol being excreted in urine by pregnant subjects in regions polluted by petrochemical/refining plants. The studies demonstrated the relationship between high levels of the excreted metabolites of aromatic hydrocarbons and abnormal afterbirth presentations [17-19]. Macroscopic, microscopic and histochemical changes were analyzed in the 1970s, 1970s and 1990s by such researchers as Zamorska, Liebhart, Radowicki, and Wierzba. Among other findings, increased presence of acidic and neutral mucopolysaccharides was observed as an evidence of compensation and adaptation mechanisms being intensified in the polluted environment [20-23]. The incidence of extraplacental membrane epithelial necrosis was higher by a factor of four in the Płock group and the number of epithelial proliferation foci in this group was also significantly higher [24]. Radowicki described extensive deposition of high quantities of antigen-antibody complexes within the intervillous space in response to environmental pollution with aromatic hydrocarbons $[25,26]$.

In this study, the researchers made use of state-of-the-art immunohistochemical methods to demonstrate whether the afterbirths obtained from normal pregnancies would show any changes (differences) in the expression of the products of the reactions of antigens used to tag individual placental functions.

To this end, we selected a group of patients so that the only "pathology" consisted of elevated phenol and 1-hydroxypyrene levels in the excreted urine while all the remaining factors remained identical in both groups.

The study material was obtained from patients with no history of disease burden whose pregnancy developed in an environment exposed to elevated atmospheric levels of aromatic hydrocarbons (HA) (the study group — Płock region) and patients from an area with no HA pollution (the control group - Kutno region). The essential condition for the afterbirth to be qualified for the study consisted of an uncomplicated, physiological course of pregnancy completed by an in-term delivery (weeks 39-41). All the observed pregnancies were completed by natural deliveries of healthy neonates (Apgar score 10). Before the pregnancy, patients were free of chronic diseases, smoking, and alcohol or drug abuse. There were no statistically significant differences between the study group and the control group in terms of age, parity, and body weight. There were no significant differences in the birth weights of children born of the analyzed pregnancies, meaning that the biological quality of children born in both towns was similar.

The study led to conclusion that the study groups differed significantly in terms of proliferative activity and apoptosis of trophoblast cells. Calculations revealed a significantly higher activity of mitotic phosphoprotein $(p<0.01)$ and a significantly higher activity of the Ki 67 antigen $(p<0.01)$ in trophoblast cells collected from the study group (Płock) as compared to the control group (Kutno). This means that adaptation and compensation mechanisms are initiated within the placenta in response to the destructive effect of aromatic hydrocarbons on the placental tissue. 
The results are in line with the findings of Wierzba, Radowicki, and Pawiński, who observed significant differences in the extraplacental membrane epithelium and villous epithelium. In their study, the researchers demonstrated significant necrosis and compensational proliferation of membrane- and villous epithelium being significantly higher in the placentas from the Płock region [27]. The extensive proliferation of placental villi is correlated with the high levels of mitotic phosphoprotein.

No reports could be found in the available literature regarding the phenomenon of apoptosis within the human placenta as being correlated with aromatic hydrocarbon levels. The analysis of the occurrence of apoptosis within trophoblast cells as performed in this study suggests that the activity of apoptosis inhibition is significantly higher in the study group due to the significantly higher activity of oncoprotein bcl-2, with oncoprotein p53 activity levels being simultaneously higher in the control group. With no doubt, this constitutes another evidence for active protection of the fetus upon environmental exposure to aromatic hydrocarbon pollutants.

Wierzba and Radowicki have shown that the endocrine activity of the placental tissue and the metabolic activity obtained after delivery from women with elevated levels of phenol and 1-hydroxypyrene in the excreted urine is statistically significantly lower compared to patients who are not exposed to aromatic hydrocarbons [28].

Liebhart reported the commonly observed remodeling of terminal villi, higher numbers of Hofbauer cells and more common occurrence of proliferative villi as changes suggestive of adaptation mechanisms being in force in the placentae of women from the Płock region $[20,21]$. Proliferative villi are observed in chronic hypoxia and are suggestive of disturbances within the adaptation mechanism responsible for the intensified exchange between the placenta, the fetus, and the mother. The efficacy of these mechanisms is sufficient to prevent marked hypoxia despite the thickening of the basal membrane of the trophoblast within the terminal villi, and therefore the biological quality of the neonates is similar in both regions [20, 25-27].

Wierzba, Radowicki at al. demonstrated that the foetus is protected by activation of adaptation and compensation mechanisms that are manifested as active angiogenesis and formation of new blood vessels that provide proper nutrition and oxygen supply to the foetus and significantly greater development of mesenchymal cells compared to the control group [29].

\section{CONCLUSIONS}

The development of the pregnancy within regions of petrochemical pollution with aromatic hydrocarbons has a negative impact on the quality of human placental tissue.
Proliferative activity of cells in the placentae of women with elevated levels of phenol and 1-hydroxypyrene being excreted with urine is statistically significantly higher than in the control group.

Statistically higher inhibition of apoptosis was observed in the placentae of women with elevated levels of phenol and 1-hydroxypyrene being excreted with urine as compared to the control group.

The observed phenomena are indicative of extensive adaptation and compensation mechanisms taking place in response to the detrimental effect exerted by aromatic hydrocarbon metabolites on the placental tissue.

\section{Conflict of interest}

The authors declare no conflict of interest.

\section{Contribution statement}

All authors conceived the idea for the study. All authors contributed to the design of the research. All authors edited and approved the final version of the manuscript.

\section{REFERENCES}

1. Faber JJ. Placental Physiology. Raven Press, NY; 1983.

2. Fox H, Sebire NJ. Pathology of the Placenta. Saunders Elsevier; 2007.

3. Perrin E. Pathology of the Placenta, Churchil Livingstone; 1984

4. Lin CM, Li CY, Mao IF. Increased risks of term low-birth-weight infants in a petrochemical industrial city with high air pollution levels. Arch Environ Health. 2004; 59(12): 663-668, doi: 10.1080/00039890409602951, indexed in Pubmed: 16789475.

5. Hirasawa G, Takeyama J, Sasano H, et al. 11Beta-hydroxysteroid dehydrogenase type II and mineralocorticoid receptor in human placenta. J Clin Endocrinol Metab. 2000; 85(3): 1306-1309, doi: 10.1210/jcem.85.3.6429, indexed in Pubmed: 10720080.

6. McConnell EE. Enviromental Health Criteria 150. Benzen World Health Organization Geneva, Geneva 1993.

7. Van Es. Enviromental Health Criteria 170. Tetrabromobisphenol World Health Organization, Geneva 1995.

8. Pawlicki L, Smoczyński S, Jaworski J.Chlorowane węglowodory we krwi położnic z rejonu Olsztyna. Problemy Lekarskie. 1982; 21(2): 229-237 [Polish].

9. Browning E. Toxicity and metabolism of industrial solvens. Elsevier, Londyn 1965

10. Yang $\mathrm{CY}$, Cheng BH, Hsu TY, et al. Association between petrochemical air pollution and adverse pregnancy outcomes in Taiwan. Arch Environ Health. 2002; 57(5): 461-465, doi: 10.1080/00039890209601438, indexed in Pubmed: 12641190.

11. Xu X, Cho SI, Sammel M, et al. Association of petrochemical exposure with spontaneous abortion. Occup Environ Med. 1998; 55(1): 31-36, indexed in Pubmed: 9536160.

12. Liebhart M, Pawiński $R$, et al. Badania patomorfologiczne kosmówki wczesnej ciąży u kobiet z podwyższonym wydalaniem fenolu i parakrezoli w moczu. Ginekol Pol 1980: 51(6): 11-13 [Polish].

13. Brzeźnicki S, Jakubowski M. Jedno-hydroksypiren jako biologiczny marker narażenia na wielopierścieniowe węglowodory aromatyczne. Instytut Medycyny Pracy. Instytut Medycyny Pracy, Łódź 1995.

14. Lis E, Garlej T. Test fenolowy w moczu jako wykładnik narażenia na węglowodory aromatyczne. Medycyna Pracy. 1978; 29(1): 32-35.

15. Schönfelder G, Wittfoht W, Hopp H, et al. Parent bisphenol A accumulation in the human maternal-fetal-placental unit. Environ Health Perspect. 2002; 110(11): A703-A707, indexed in Pubmed: 12417499.

16. Boogaard PJ, van Sittert NJ. Exposure to polycyclic aromatic hydrocarbons in petrochemical industries by measurement of urinary 1-hydroxypyrene. Occup Environ Med. 1994; 51(4): 250-258, doi: 10.1136/oem.51.4.250, indexed in Pubmed: 8199667. 
17. Pelkonen $\mathrm{O}$, Saarni H. Unusual patterns of benzo[a]pyrene metabolites and DNA-benzo[a]pyrene adducts produced by human placental microsomes in vitro. Chem Biol Interact. 1980; 30(3): 287-296, doi: 10.1016/0009-2797(80)90051-4, indexed in Pubmed: 7379208.

18. Lösch A, Kainz C. Immunohistochemistry in the diagnosis of the gestational trophoblastic disease. Acta Obstet Gynecol Scand. 1996; 75(8): 753-756, doi: 10.3109/00016349609065741, indexed in Pubmed: 8906012.

19. Chen $\mathrm{D}, \mathrm{Cho} \mathrm{SI}$, Chen $\mathrm{C}$, et al. Exposure to benzene, occupational stress, and reduced birth weight. Occup Environ Med. 2000; 57(10): 661-667, doi: 10.1136/oem.57.10.661, indexed in Pubmed: 10984337.

20. Liebhart $\mathrm{M}$, et al. Badania mikroskopowe popłodu $\mathrm{z}$ ciąży donoszonej z uwzględnieniem zmian toksykologicznych stwierdzonych u matki. Ginekol Pol 1882; 53(4): 221-27. Ginekol Pol. 1882; 53(4): 221-227.

21. Radowicki S. Praca Zbiorowa, Porównanie przebiegu ciąży na terenie miast - Kutna i Płocka. TNP, AM, UW, Warszawa, Płock 1992

22. Radowicki S, Wierzba W. Popłód z ciąży prawidłowej przebiegającej w terenie skażonym ekologicznie (Płock). Ginekol Pol 1997; 68(5b): 63-67 [Polish].

23. Zamorska L. Aktywność enzymów utleniających i morfologia łożysk ludzkich z ciąż donoszonych. Folia Medica Cracoviensia 1982/1983; 24(1-1PL): 67-87 [Polish].
24. Liebhart $\mathrm{M}$, et al. Rembiszewska Badania histologiczne i histochemiczne popłodu z wczesnych okresów ciąży u kobiet pracujących w środowiskowych warunkach zakładów rafineryjnych. Sprawozdanie z umowy $\mathrm{Nr} 23$ z MZRiP, 1978 [Polish].

25. Radowicki S, WierzbaW. Macroscopic evaluation of placenta from ecologically-challenged area (Plock), part I. Ginekol Pol 1997;68(2):64-68 [Polish].

26. Radowicki S, Wierzba WM. [The duration of pregnancy in ecologically-challenged area (Plock)]. Ginekol Pol. 1997; 68(2): 53-58, indexed in Pubmed: 9498996.

27. Wierzba W, Radowicki S, Pawiński R. Microscopic evaluation of placenta from ecologically-challenged area (Plock) - Part I. Ginekol Pol 1997; 68(3): 109-113 [Polish].

28. Wierzba W, Radowicki S, Bojar I, et al. Effects of environmental pollution with aromatic hydrocarbons on endocrine and metabolic functions of the human placenta. Ann Agric Environ Med. 2017, doi: 10.26444/aaem/74406.

29. Wierzba W, Radowicki S, Bojar I, et al. The duration of pregnancy in ecologically-challenged area. The effects of environmental pollution with aromatic hydrocarbons on the angiogenesis and elements of the mesenchymal tissue of the human placenta. Ginekol Pol. 2017; 88(4): 180-184, doi: 10.5603/GP.a2017.0035, indexed in Pubmed: 28509318. 